\title{
Mindfulness, Problem-solving Skills and Academic Achievement: Do Perceived Stress Levels Matter?
}

\section{Bilinçli Farkındalık, Problem Çözme Becerisi ve Akademik Başarı: Algılanan Stres Düzeyi Önemli Mi?}

\author{
Melih DİKMEN*
}

Received: 31 May 2021

Research Article

Accepted: 10 August 2021

ABSTRACT: This study examines the relationship between higher education students' perceived stress levels, and their problem solving skills, awareness levels and academic achievement. Also, the mediating role of mindfulness levels and problem-solving skills on the association between perceived stress level and academic achievement was investigated. The research was designed according to the correlational research design, one of the quantitative research methods. The participants of the study consisted of 938 higher education students. For data collection, three different questionnaires were administered to the participants. In addition, the personal information form prepared by the researcher was used to obtain the students' demographic characteristics and grade point averages (GPA). The results showed that there was a significant negative relationship between perceived stress levels of higher education students and their mindfulness, problem solving skills, and academic achievement. Also, it was found that mindfulness and problem-solving skills had a mediating role in the association between perceived stress level and academic achievement. Based on the findings of the study, it was concluded that mindfulness-based approaches and problem-solving skills are important for higher education students to reduce their stress levels and increase academic success. The limitations and recommendations for future research are discussed.

Keywords: Academic achievement, problem-solving skills, mindfulness, perceived stress, higher education students.

ÖZ: Bu çalışma yükseköğretim öğrencilerinin algılanan stres düzeyleri ile problem çözme becerileri, bilinçli farkındalık düzeyleri ve akademik başarıları arasındaki ilişkiyi incelemeyi amaçlamaktadır. Ayrıca algılanan stres düzeyi ile akademik başarı arasındaki ilişkide bilinçli farkındalığın ve problem çözme becerisinin aracılık rolü araştırılmıştır. Araştırma, nicel araştırma yöntemlerinden ilişkisel tarama modeline göre tasarlanmıştır. Araştırmanın katılımcıları 938 yükseköğretim öğrencisinden oluşmaktadır. Veri toplama aracı olarak katılımcılara üç farklı̈ ölçek uygulanmıştır. Ayrıca araştırmada öğrencilerin demografik özelliklerini ve yılsonu not ortalamalarını (GNO) elde etmek için araştırmacı tarafından hazırlanan kişisel bilgi formu kullanılmıştır. Sonuçlar, yükseköğretim öğrencilerinin algılanan stres düzeyleri ile bilinçli farkındalıkları, problem çözme becerileri ve akademik başarıları arasında anlamlı negatif bir ilişki olduğunu göstermiştir. Ayrıca algılanan stres düzeyi ile akademik başarı arasındaki ilişkide bilinçli farkındalık ve problem çözme becerilerinin aracı rolü olduğu bulunmuştur. Araştırmanın bulgularına göre farkındalık temelli yaklaşımların ve problem çözme becerilerinin yükseköğretim öğrencilerinin stres düzeylerini azaltarak akademik başarılarının artması açısından önemli olduğu belirlenmiştir. Gelecekteki araştırmalar için bazı sınırlılıklar ve öneriler tartışılmıştır.

Anahtar kelimeler: Akademik başarı, problem çözme becerileri, bilinçli farkındalık, algılanan stres, yükseköğretim öğrencileri.

\footnotetext{
* Dr., Firat University, Elazı ğ, Turkey, melihdikmen @ gmail.com, https://orcid.org/0000-0001-7015-6236
}

Citation Information

Dikmen, M. (2022). Mindfulness, problem-solving skills and academic achievement: Do perceived stress levels matter?. Kuramsal Eğitimbilim Dergisi [Journal of Theoretical Educational Science], 15(1), 42-63. 
Stress has become a common denominator in dynamic, more developed, and complex societies. According to Lazarus and Folkman (1984), "stress is a particular relationship between the person and the environment that is appraised by the person as taxing or exceeding his or her resources and endangering his or her well-being". The effects of stress are directly related to one's threat perceptions, vulnerability, and coping skills. Although stress helps individuals achieve success at a normal level, it causes many physiological and psychological issues when it becomes chronic (Patel, 1989). More specifically, performance loss is observed in the execution of neural systems related to learning and memory in the brain when individuals produce a response to high stress (Gürbüzer, 2016), which results in a negatively influenced learning process. Therefore, high level of stress not only impairs the health and well-being of an individual but also causes a decrease in academic success (Bernal-Morales et al., 2015; Elias et al., 2011). In addition, stress causes a decrease in motivation (Liu, 2015) and an increase in dropout rates (Walburg, 2014). Studies indicated that higher education students' stress levels are critically high (Pascoe et al., 2020), which can negatively influence the learning process in those higher education institutions.

There exist many factors that affect students' stress levels. According to the transactional stress model of Lazarus and Folkman (1984), individuals experience stress based on how they evaluate the situation they are in. According to the model, when individuals face a stressor, they evaluate it to determine whether it is stressful, positive, controllable, or irrelevant. If it is stressful, then they examine their coping skills by considering balance of demands (e.g., risks, challenge, and uncertainty) and available resources (e.g., social support and expertise). Stress increases in situations when demands are more than resources (Lazarus \& Folkman, 1984). Another situation that causes higher education students to feel stress is their separation from family and increased academic demands (Pascoe et al., 2020). Also, a significant relationship was observed between low life quality and well-being and stress (Ribeiro et al., 2018). Students' high stress levels are also related to serious health problems such as depression and anxiety (Moylan et al., 2013). In addition, major stressful life events are one of the predictors of the onset of depression (Kessler, 1997). In a study conducted in the United States, it was determined that students who reported constant stress regarding the admission process in higher education institutions and academic expectations during higher education tend to use drugs and alcohol at a high rate (Leonard et al., 2015). Stress also is related to sleep disorder among adolescents (Curcio et al., 2006; Wallace et al., 2017). The abovementioned studies revealed that stress has negative effects on higher education students.

One of the most commonly used methods in studies focusing on stress is to determine the perceived stress levels of individuals (Vallejo et al., 2018). Perceived stress is related to the individual's personal feelings or thoughts about to what extent he/she is under stress in a certain time period (Phillips, 2013). The concept of perceived stress has a dynamic and multidimensional structure due to the fact that perceptions include physical, psychological, and psychosocial aspects and have both cultural and social dimensions (Moore \& Cooper, 1996). In this context, individuals' perceived stress levels and reactions are directly influenced by various variables, including their personality traits, lifestyles, social support, life events, socio-demographic characteristics, and occupation (Feizi et al., 2012). As a result, the variation in 
individuals' stress levels and their reactions to similar situations is explained by the concept of perceived stress (Cohen et al., 1983). The studies in the literature reveal that perceived stress is negatively associated with mindfulness (Atanes et al., 2015), problem-solving skills (Largo-Wight et al., 2005), self-efficacy (Han, 2005; Park et al., 2008), life satisfaction (Lee et al., 2016), happiness (Schiffrin \& Nelson, 2010), and academic achievement. Therefore, individuals' perceived stress levels include individual differences and may have negative effects on them.

Considering the negative effects of stress on learners, it is critical to diagnose stress and investigate its relation with certain factors, one of which is individuals' mindfulness levels. Perhaps the most widely used definition of mindfulness is "paying attention in a particular way: on purpose, in the present-moment and non-judgmentally" (Kabat-Zinn, 1990). Mindfulness helps people reduce their negative thoughts and feelings without making any judgment and decrease their emotional difficulties and distress (Gilbert, 2005). It encourages individuals to react less emotionally to external stressors (Arch \& Craske, 2010) and repetitive thoughts (Feldman et al., 2010). As a result, individuals tend to accept them as they are rather than attempting to change their emotional experiences (Lutz et al., 2008). A high level of mindfulness contributes positively to individuals' mental health, relationship satisfaction, and coping with stress (Brown et al., 2009). Mindfulness is also related to psychological well-being (Deniz et al., 2017). Mindfulness, which is also effective in regulating emotions, supports individuals to perceive and regulate their or others' emotions appropriately (Koole, 2009). Moreover, Mindfulness-based Stress Reduction Methods (MBSR) effectively reduce individuals' stress levels (Kabat-Zinn, 1990; Shapiro et al., 2005). As a result of the "Mindfulness-Based Stress Reduction" program applied by Miller et al. (1995) to patients with anxiety disorders, it was found that individuals' stress levels and anxiety symptoms significantly decreased. Furthermore, it is stated that students with high level of mindfulness are more successful in coping with stress (Weinstein et al., 2009) and experience less depression and anxiety issues (Allen et al., 2017; Egan \& Mantzios, 2018). Mindfulness also has a positive influence on one's well-being both physically and mentally (Horan \& Taylor, 2018). Conversely, a low level of mindfulness can cause, for instance, a lower level of motivation, which can result in depression or anxiety (Keng et al., 2011). Thus, intervention programs focusing on mindfulness and compassion can support individuals to overcome some mental health issues (Wamsler, 2018). Based on the discussions above, it is considered that mindfulness is a critical factor that influences individuals' stress levels.

Another variable that is effective on stress is individuals' problem-solving skills (Abdollahi et al., 2018). Specifically, interventions on learners' problem solving skills can decrease students' stress levels and increase self-efficacy (Moattari et al., 2001). The problem-solving process includes cognitive and behavioral dimensions that contain higher order thinking, such as determining, choosing, and making decisions about effective solutions (D'Zurilla \& Nezu, 2001). There can be individual differences in the organization and execution of these dimensions (Lazarus \& Folkman, 1984), resulting in individuals reacting differently to problems they encounter. For instance, in case of a problematic situation, individuals may pretend that there is no problem, delay decisions, ask others to find solutions, and/or wait for the problem to be solved on its own (Korkut, 2002). When the problem-solving skills are not developed sufficiently or are 
not used effectively, psychological disorders such as depression, anxiety, and stress can develop (D'Zurilla \& Nezu, 2007). In addition, problem solving skills are significantly related to individuals' stress perceptions (Heppner et al., 2004) and stress levels (Abdollahi et al., 2018). Moreover, problem solving skills serve as a shield in negative situations to protect individuals (Klaassens, 1992). Studies in the literature show that stress and problem solving skills are interrelated.

As seen above, mindfulness (Bishop, 2002; Carmody \& Baer, 2008; Grossman et al., 2004; Janssen et al., 2018; Shapiro et al., 2005) and problem-solving skills (Braun-Lewensohn et al., 2014; Largo-Wight et al., 2005; Tan et al., 2019; Yu, 2018) have an important effect in reducing the stress level of students. However, there can be a two-way relationship between mindfulness and problem-solving skills and stress. While it is thought that an individual with a high level of mindfulness can keep the stress level under control, the mindfulness level of an individual with a high level of stress can decrease and this decrease can cause more stress (Arslan, 2018). Similarly, the relationship between problem-solving skills and stress levels can differ in terms of cause and effect. While problem-solving skills can be a factor in reducing stress levels, an increase in stress level can be associated with a decrease in problem-solving skills. The perceived stress level can cause students' important skills, including mindfulness (Von der Heyde, 2017) and problem-solving skills (Hittinger, 2018), to be dysfunctional, which results in uncontrollable and increasing stress. This situation can negatively affect academic achievement (Khan et al., 2013) and, as a result, career planning (Infantolino, 2017) and future expectations (Florêncio et al., 2017). While an optimal level of stress can advance individuals' learning skills (Kaplan \& Sadock, 2000), high levels of stress can cause physical and mental health problems (Niemi \& Vainiomäki, 1999) and decrease students' academic achievement (Elliot et al., 2005; Hofer, 2007; Trautwein et al., 2006). Although a number of strategies are used to control students' stress levels, in some cases, it is very difficult to administer stressreducing interventions. Especially, the current COVID-19 epidemic has significant influences on individuals' stress level (Brooks et al., 2020) and, in turn, affects their academic achievement (Marinoni et al., 2020). This may be explained through the fact that high level of stress negatively stimulates learning and memory, which negatively influences academic achievement (Mehfooz \& Haider, 2017; Sindhu, 2016; Sohail, 2013). Therefore, it is critical to determine the effective factors in controlling high stress. Many studies in the literature focus on mindfulness (Hede, 2017; Olendzki et al., 2020; Sagui-Henson et al., 2018) and problem-solving skills (Chew-Graham et al., 2003; Gupta et al., 2015) and their effects on stress. However, the possible effects of stress on mindfulness and problem-solving skills were not examined sufficiently. In addition to this, examining whether mindfulness and problem-solving skills are effective in reducing the negative effect of stress on academic achievement may be important in terms of the efficiency of teaching and learning activities.

\section{Current Research}

Based upon the aforementioned theoretical and empirical literature, several questions need to be investigated regarding the relationship between perceived stress, academic achievement, mindfulness, and problem-solving skills in the context of higher education students. Consequently, the primary aim of the current study is to examine the 
association among stress level, mindfulness, problem-solving skills, and academic achievement. In addition, the mediating role of problem solving skills and mindfulness in the relationship between perceived stress and academic achievement is tested. In the literature, it is seen that there are studies examining the relationship of perceived stress with academic achievement (Elliot et al., 2005; Hofer, 2007), problem solving skills (Largo-Wight et al., 2005), and mindfulness (Atanes et al., 2015). However, no research has been found in which any structural model has been tested on the mediating effect of mindfulness and problem-solving skills in the relationship between stress and academic achievement. In this respect, the research results may be important in reducing the negative effects of stress and increasing academic achievement. As a matter of fact, it was stated that mindfulness-based approaches can effectively reduce stress (Kabat-Zinn, 1990) and increase academic achievement (Caballero et al., 2019). Moreover, it was found that problem solving skills were effective in reducing perceived stress (Abdollahi et al., 2018) and there was a positive significant correlation between problem solving skills and academic achievement (Perveen, 2010). In this context, seven research question have been proposed: (i) is there any relationship between perceived stress and academic achievement? (ii) does perceived stress significantly predict academic achievement? (iii) is there any relationship between perceived stress and mindfulness? (iv) does perceived stress significantly predict mindfulness? (v) is there any relationship between perceived stress and problem solving skills? (vi) does perceived stress significantly predict problem solving skills? (vii) is there any mediating role of mindfulness and problem solving skills on the association between perceived stress and academic achievement? Accordingly, the proposed model for the path analysis is presented in Figure 1.

Figure 1

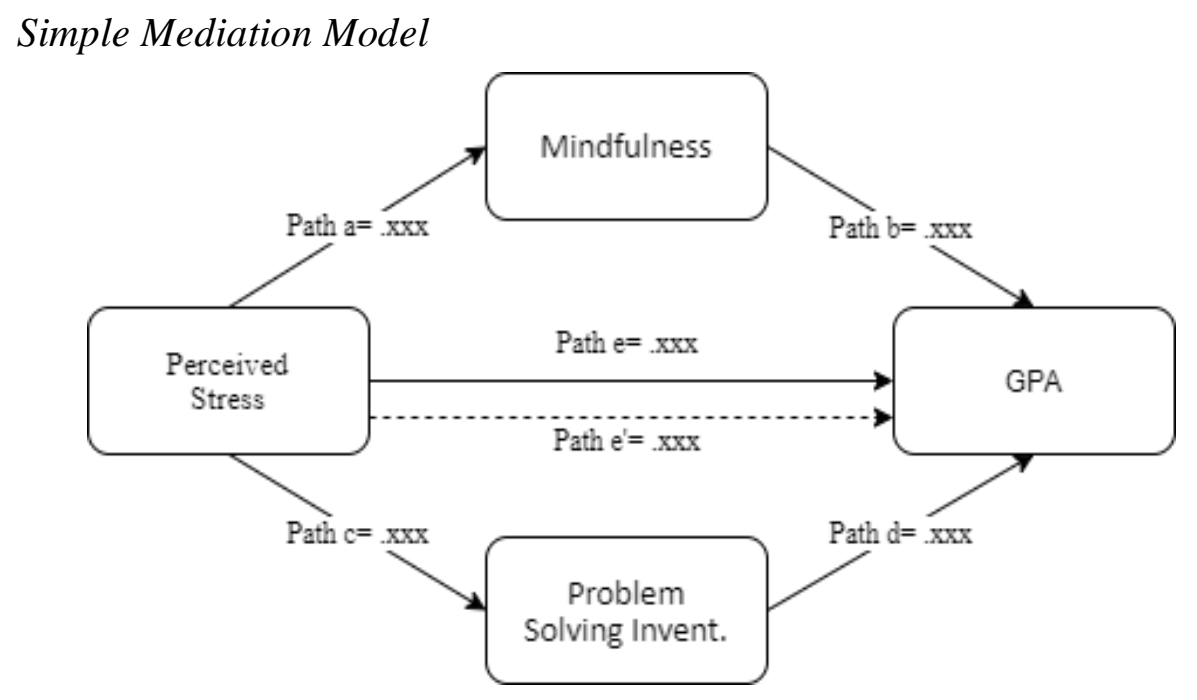

\section{Method}

This quantitative study was designed based on a correlational research design by using independent and dependent variables within the scope of the study. In correlational study, "the researcher examines whether and to what degree a statistical relationship exists between two or more variables" (Mertler, 2016). Before conducting the study, a model that presents the expected associations among the variables should be 
proposed and, then, the model is tested (Glasow, 2005). In the current study, while perceived stress level $(\mathrm{X})$ is considered an independent variable, academic achievement $(\mathrm{Y})$ is considered a dependent variable. In addition, problem solving skills (M1) and mindfulness (M2) were treated as moderator variables in the association between the dependent and independent variables.

\section{Participants}

Participants of the study were recruited through a snowball sampling method. In order to employ the snowball sampling method, a connection is made to any unit in the universe. This unit encourages others to participate in the study, which results in an increase in sample size. This continues as a chain until a sufficient number of participants is recruited (Gürbüz, 2018). The rationale of using the snowball sampling method in this research is the difficulty of reaching out to the subjects in the universe to assemble them as participants. Also, through this method, data saturation (Kerlinger \& Lee, 1999) was ensured. Turkey is divided into seven regions geographically. From each region, one university was identified. Then, the participant selection procedure was started. According to Flick (2014), researchers should reach people whom they think have the most information about the phenomenon researchers are interested in and investigate. Thus, one research assistant at the Faculty of Education in each university was reached. A total of seven research assistants were introduced about the study and confidentiality of the study. The participants of the study were recruited through these research assistants. As a result, a total of 938 students from seven public universities were reached out. Descriptive statistics of the participants are presented in Table 1.

Table 1

Descriptive Statistics of the Participants

\begin{tabular}{ll}
\hline Variable & Statistics \\
\hline Age & Age range: $18-26 ;$ average age $=23.04, S D=2.89$ \\
\hline Sex & Male=445 $(47.4 \%)$, Female $=493(52.6 \%)$ \\
\hline & Natural Applied Sciences $=253(52.3 \%)$ \\
Field Type & Humanities \& Social Sciences $=496(41.9 \%)$ \\
& Healthcare Sciences $=387(5.8 \%)$ \\
\hline
\end{tabular}

The age range of the students in this study was between 18 and 26. There were $445(47.4 \%)$ male and $493(52.6 \%)$ female students. Also, based on the preliminary analysis, it was found that $687(73.1 \%)$ were undergraduate students and the rest $(26.8 \%)$ were community college students. In addition, there were 496 students from the social studies-related departments, 55 students from the health-related departments, and 387 students from the natural applied sciences departments. In this direction, students from various fields were included in the study.

\section{Instruments}

In this study, a demographic information form and three scales were administered for data collection. The participants were asked to report their gender, field, and grade point averages (GPA) through the demographic information form. The 
first scale of the study was the mindful attention awareness scale (MAAS) developed by Brown and Ryan (2003) and adapted into Turkish by Özyeşil et al. (2011). This scale consists of fifteen items. An example item from the scale is that "I could be experiencing some emotion and not be conscious of it until sometime later." The scale has one dimension and is designed as a six-point Likert type ranging from 1 (almost always) to 6 (almost never). A higher score refers to higher mindfulness. While the Cronbach's alpha value was calculated as .90 by Özyeşil et al. (2011), it was .82 in this particular study.

The second scale in this study was the perceived stress scale (PSS) developed by Cohen et al. (1983) and adapted into Turkish by Eskin et al. (2013). The five-point Likert type scale ranging from 0 (never) to 4 (very often) consists of fourteen items. An example item from the scale is that "how many times did you feel angry and stressful last month?" The scale has two dimensions: perceived insufficient self-efficacy (PISE) and perceived stress/ distress (PSD). While the Cronbach's alpha value was calculated as .84 by Eskin et al. (2013), it was found to be .91 in this particular study.

The last scale was the problem-solving skills inventory (PSSI) developed by Heppner and Petersen (1982) and adapted to Turkish by Taylan (1990). The six-point Likert type inventory includes thirty-five questions ranging from 1 (never) to 6 (always). An example item is that "When confronted with a problem, I tend to do the first thing that I can think of to solve it." The scale has three dimensions: confidence in problem-solving (CPS), approach avoidance attitude (AAA), and ability to maintain personal control (AMPC). While Taylan (1990) calculated the Cronbach Alpha value as .86 , it was .89 for this study.

\section{Data Collection Process}

The questionnaires used in this study were transferred into electronic format via Google Forms. The link and the consent forms were sent out to the participants. The consent form included a general description of the study and confidentiality and privacy issues. The students willing to participate in the study filled out the data collection tools in an online environment. The study was carried out in the fall semester of the 20202021 academic year. This study received ethics approval from the Social and Human Sciences Research Committee of Firat University (dated 28.05.2020, E-97132852302.14.01-48437).

\section{Data Analysis}

There were a total of 972 cases for preliminary analysis. Before the data analysis process, the data was checked to determine any missing or invalid data. There were 34 cases with missing or invalid data. Therefore, they were dropped out from the analysis, which left 938 cases. In the next step, Mahalanobis distance and $\mathrm{z}$ scores were calculated to determine the outliers in the data set. The results revealed that there were no outliers since $\mathrm{z}$ scores between -3 and +3 are accepted as an indication that there is no extreme value in the data set (Osborne \& Amy, 2004). In order to examine the correlations among the variables, Pearson product-moment correlation analysis was performed. Also, a linear regression analysis was run in order to determine the predictability of stress on mindfulness, problem solving skills, and academic achievement. For regression analysis, there exist assumptions to be met: the absence of 
linearity, normality and multicollinearity problem. In this context, the data was examined for normality and linearity. According to Tabachnick and Fidell (2007), the skewness and kurtosis values need to be between -1.5 and +1.5 for the data to be considered normally distributed. The preliminary analysis of the data revealed that the normality assumption was met. Moreover, in order to identify whether multicollinearity exists in the data set, the correlation levels of the variables were examined by using variance inflation factor (VIF). An acceptable VIF value needs to be <5.0 (Hair et al., 2010). It was determined that there were no multiple associations between variables. For structural equation modeling, various fit indices are taken into account. Specifically, the RMSEA value is accepted as a good fit if it is 0.05 or below and it is considered as an acceptable fit if it is between .05 and 0.1 Also, GFI, AGFI, CFI, and IFI values close to 1 indicate a good fit (Schermelleh-Engel et al., 2003). Mediation analyses were performed using the PROCESS program developed by Hayes (2013). PROCESS contains macros (template models) for 92 different models that help calculate mediating and regulatory effects (Hayes, 2018). PROCESS is a program that works as an add-on to SPSS. In the research, structural equation modeling was performed to evaluate the fit of the proposed model using the AMOS 22. Data were analyzed using the SPSS 22 package.

\section{Results}

First, the descriptive statistics for the scales and the correlations among them were obtained. The results are provided in Table 2.

Table 2

Means, Standard Deviations, and Correlation Results

\begin{tabular}{lccccc}
\hline Variables & $M$ & $S D$ & 1 & 2 & 3 \\
\hline 1: PSS & 27.77 & 7.22 & - & & \\
2: GPA & 69.53 & 13.63 & $-133^{* *}$ & - & \\
3: MAAS & 56.12 & 10.66 & $-.497^{* *}$ & $.137^{* *}$ & - \\
4: PSSI & 126.37 & 15.16 & $-.406^{* *}$ & $.166^{* *}$ & $.375^{* *}$ \\
\hline \multicolumn{1}{c}{$* * .001$} & & & & &
\end{tabular}

As seen in Table 2, it was determined that participants' perceived stress level was $27.77 \pm 7.22$, overall GPA was $69.53 \pm 13.63$. In addition, the mean score for the MAAS was $56.12 \pm 10.66$ and the mean score for the PSSI was $126.37 \pm 15.16$. The analysis results revealed that the perceived stress levels had a moderate and negative correlation with mindfulness ( $r=-.497)$ and problem-solving skills ( $r=-.406)$, and a small and negative correlation with GPA ( $r=-.133)$. In addition, small and positive correlations were found between GPA and mindfulness $(r=.137)$ and problem-solving skills $(r=.166)$. It was also found that there was a moderate and positive correlation between mindful awareness and problem-solving skills $(r=.375)$. The correlation among dependent, independent, and mediating variables was found to be significant at the .001 level. 
In line with the study's purpose, it aimed to determine the predictive power of the perceived stress levels on mindfulness, problem-solving skills, and GPA. The preliminary analysis results revealed that the data was suitable for regression analysis. The results are provided in Table 3.

Table 3

The Regression Analysis Results

\begin{tabular}{llccccccccc}
\hline Predictive & Predicted & $R$ & $R^{2}$ & $B$ & $S E$ & $\beta$ & $t$ & $p$ & $F$ & $p$ \\
\hline PSS $\rightarrow$ & GPA & .14 & .02 & -.263 & .061 & -.140 & 43.811 & .000 & 18.575 & .000 \\
PSS $\rightarrow$ & MAAS & .50 & .25 & -.733 & .042 & -.497 & 63.649 & .000 & 306.67 & .000 \\
PSS $\rightarrow$ & PSSI & .41 & .17 & -.852 & .063 & -.406 & 83.40 & .000 & 184.48 & .000 \\
\hline
\end{tabular}

As seen in Table 3, students' perceived stress levels negatively predicted students' GPA, mindfulness level, and problem-solving skills. According to the results, perceived stress predicts $2 \%$ of the variance related to GPA, $25 \%$ of the variance for mindfulness level, and $17 \%$ of the variance for problem-solving skills. When the standardized coefficient $(\beta)$ and t values are examined, it is seen that the increase in the perceived stress levels of the students had a significant negative effect on their GPA, mindfulness levels, and problem-solving skills. In order to better interpret the findings, the regression plots were created and are presented in Figure 2.

Figure 2

The Regression Plots
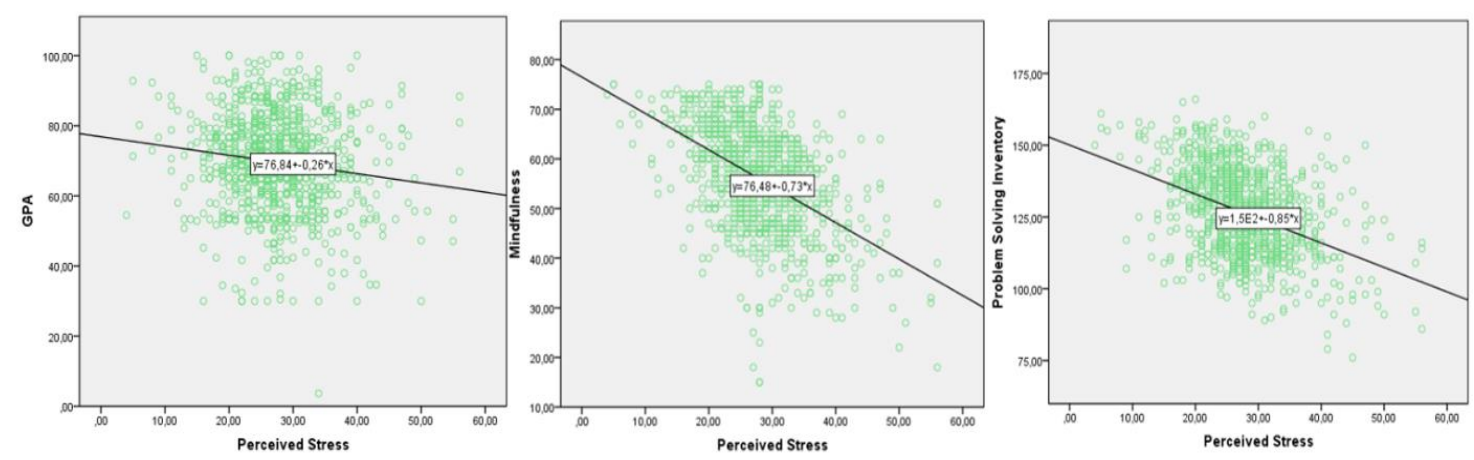

Figure 2 shows that as students' perceived stress levels increase, their GPA, mindfulness levels, and problem-solving skills decrease linearly, proving that the perceived stress levels negatively predict academic achievement, mindfulness levels, and problem-solving skills.

Structural equation modeling was performed to evaluate the fit of the proposed model. No modifications were made to the model for the path analysis (Figure 3). 
Figure 3

\section{Multiple Mediation Model}

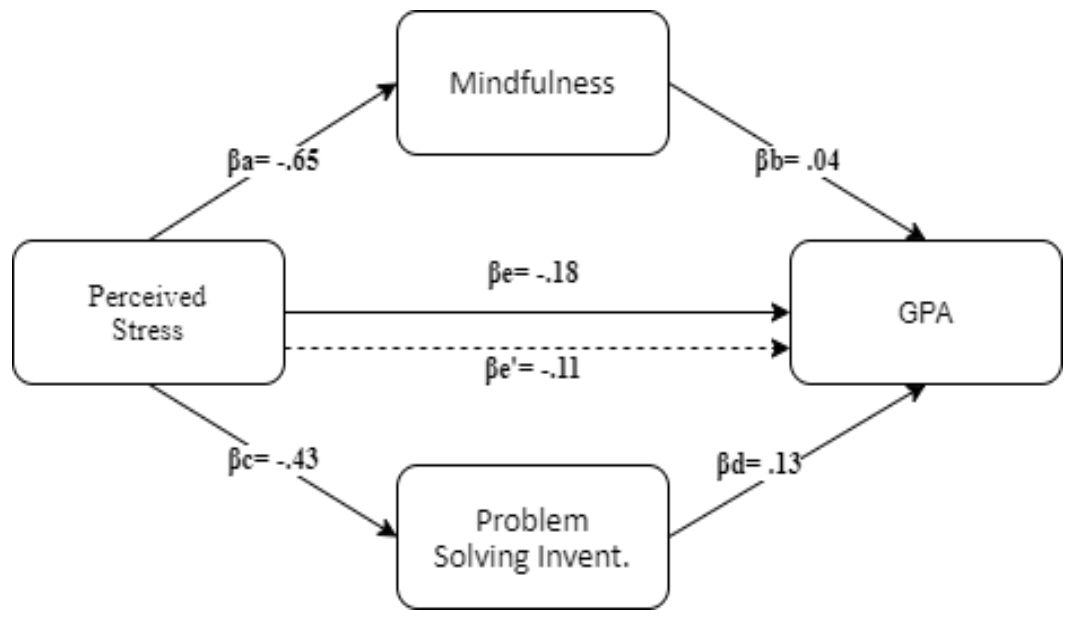

It was determined that the perceived stress levels negatively predicted GPA ( $\beta e=-.18, S E=.011, t=-3.101, p=.002)$. In the new model established with mediator variables, perceived stress levels were found to negatively predict mindfulness $(\beta a=-.65$, $S E=.262, t=-11.503, p<.001)$ and problem-solving skills $(\beta c=-.43, S E=.270, t=-5.352$, $p<.001)$. When the perceived stress levels, problem-solving skills, and mindfulness were taken into the model simultaneously, it was determined that the relationship between perceived stress levels and GPA changed from -.18 to -.11, which supports the mediation hypothesis. Specifically, the negative effect of perceived stress levels on GPA was reduced by mindfulness $(\beta b=.04)$ and problem-solving skills $(\beta d=.13)$. The results of the analysis showed that the mediation effect was significant and within the expected confidence interval $(C I=-.010,-.003)$. If this confidence interval does not contain zero, mediation is considered to be present (Field, 2013).

The fit indices of the models related to the mediating role of mindfulness (Model 1) and problem-solving skills (Model 2) in the relationship between perceived stress levels and GPA are presented in Table 4.

Table 4

Summary of Goodness of Fit Statistics for Two Models

\begin{tabular}{ccccccccc}
\hline & $d f$ & $X^{2}$ & AGFI & GFI & CFI & TLI & RMSEA & SRMR \\
\hline Model 1 & 1 & 2.271 & .99 & .99 & .99 & .98 & .04 & .01 \\
Model 2 & 1 & 4.396 & .98 & .99 & .99 & .95 & .06 & .02 \\
\hline
\end{tabular}

As seen in Table 4, fit indices for both models were at an acceptable level (Schermelleh-Engel et al., 2003).

\section{Discussion and Conclusion}

This study examined the association among higher education students' perceived stress levels, mindfulness, problem solving skills, and academic achievement. The results revealed that there was a significant and negative relationship between perceived stress levels and academic achievement. Also, the perceived stress levels negatively 
predicted academic achievement. These findings are parallel to the findings of the other studies in the literature (Choi et al., 2007; Elias et al., 2011; Herath, 2019; Rafidah et al., 2009). In a study, Veena and Shastri (2016) stated that students' stress levels with high and low academic performance differ significantly. In this context, it is concluded that there is a significant negative relationship between students' stress levels and their academic achievement. Accordingly, it can be said that as the perceived stress levels of higher education students increase, academic achievement may decrease.

In the study, a significant negative relationship was found between perceived stress levels and mindfulness. Also, the perceived stress levels are a significant negative predictor of mindfulness. In other words, as higher education students' perceived stress levels increased, their mindfulness levels decreased. Similar findings were observed in other studies as well (Cash \& Whittingham, 2010; Cenkseven-Önder \& Utkan, 2018; De Lissnyder et al., 2012; Weinstein et al., 2009). In line with the study results, the perceived stress levels can be seen as a cause or as a result of the decrease in mindfulness. In other words, a decrease in the level of mindfulness can negatively affect individuals to contend with stress, which may result in an increase in stress level, or a high level of stress can make mindfulness dysfunctional. This indicates a negative linear structure.

Another finding of the study is the significant and negative relationship between perceived stress levels and problem-solving skills of higher education students. Also, the perceived stress levels were a significant negative predictor of problem-solving skills. In other words, as students' perceived stress levels increase, their problemsolving skills decrease. Similar results were reported in other studies (Abdollahi et al., 2018; Demir, 2019; Largo-Wight et al., 2005). The results of the study revealed how to control the association between stress and academic achievement through mindfulness and problem solving skills. A recent study reported that mindfulness-based interventions are effective in reducing anxiety, depression, and stress (Geiger et al., 2016). In a study conducted by Teodorczuk (2013), a significant relationship was found between the mindfulness levels of university students and their academic achievement. Similarly, experimental studies emphasize that a high level of mindfulness positively affects students' academic achievement (Biegel \& Brown, 2010; Franco et al., 2010; Franco et al., 2011). There are many studies reporting how mindfulness decreases stress. In a systematic-review study, out of 17 studies, 16 studies reported that mindfulness resulted in positive changes in psychological or physiological outcomes related to anxiety or stress (Sharma \& Rush, 2014). Mindfulness teaches individuals to analyze situations and thoughts in a non-judgmental manner without reacting to them thoughtlessly. In addition, it helps people develop a more automatic awareness of experience and can be an effective tool to relieve stress (Baer et al., 2006; Kabat-Zinn, 1994). The findings of the current study and the other studies provide evidence that the direct negative effect of stress on academic achievement can be reduced indirectly through mindfulness. Similar to mindfulness, in the study, it was found that problemsolving skills also reduced the negative effects of perceived stress on higher education students' academic achievement. This finding also supports the findings of other studies in the literature (Olgun et al., 2010; Özyazıcıoglu et al., 2009). The problem-solving process includes high-level thinking skills such as questioning, comparing, analyzing, and synthesizing (Cabanilla-Pedro et al., 2004). Therefore, a student who develops 
problem-solving skills can be more successful in the learning process that consists of a comprehensive and complex structure. More specifically, Hassan and Rahman (2017) stated that students with advanced problem-solving skills can better understand the problem statement, plan the solution in detail, and use more metacognitive processes. The perceived stress levels of students with high problem-solving skills decreased significantly compared to those with low level of problem-solving skills (Abdollahi et al., 2018). Therefore, it can be concluded that problem-solving skills are an important factor in controlling stress and increasing academic success.

The findings of the current study indicated that as students' perceived stress level increases, their mindfulness, problem-solving skills, and academic achievement decrease. It can be said that mindfulness and problem solving skills are effective mechanisms against the negative effect of stress on academic achievement. In other words, mindfulness and problem solving skills enable individuals to generate new solutions and new perspectives in case of difficulties they encounter. This, in turn, can help individuals to control repetitive and non-productive thoughts that cause stress and increase their academic success.

\section{Implications}

There exist several limitations. The first limitation is the snowball sampling method employed to recruit participants. Researchers can encounter problems finding the right subject who reaches out to other subjects due to some difficulties, including cost, time, and process issues. In addition, the first subjects have effects on the selection of the other subjects due to their networking skills and ability to find suitable samples. Therefore, future studies must consider employing other sampling methods as well. The second limitation is that the present study is a cross-sectional study and the data was collected within a four-week interval. Thus, longitudinal studies must be designed to obtain more information about the associations among perceived stress, mindfulness, problem solving skills, and academic achievement. The third limitation of the study is that the data was collected during the COVID-19 epidemic. Brooks and colleagues (2020) revealed that the epidemic has influences on stress level. Therefore, the study should be replicated after the epidemic ends. Another limitation is related to the data collection process. The participants filled out the questionnaires online. Since there was no direct contact with the participants (face-to-face communication), there might be misconceptions about the importance of the study and data privacy. Tuncer (2017) states that online questionnaires should be used with extra care due to difficulty understanding some complex expressions in online environments. Therefore, it is suggested to test the model by collecting data in face-to-face environments. Another limitation is related to the culture of the participants. Culture is a key variable that influences the research process and the findings of a study (Lee et al., 2007). Future studies must re-test the model presented in this study by including participants from different cultures. The next limitation is the nature of path analysis and its assumptions identified by researchers. Therefore, new models must be designed and tested using different assumptions about perceived stress, mindfulness, problem solving skills, and academic achievement. In addition, the results of the study are particularly limited to the dimensions measured by the scales. Therefore, future research may test the same model with different measurements. The last limitation is the reported GPA scores. In terms of 
ethical principles, it was impossible to get school records or students' grades. Therefore, the GPA had to be reported by the students, which raise an issue about the possibility of students' misrepresentations when reporting GPA. Although numerous research found relatively high correlations between self-reported and actual GPA in the range of .70 to .90 (Kuncel et al., 2005), the reliability of self-reported grades is still a subject of debate. In this particular study, the participants were asked to fill out the demographic information form two times with a two-week interval. The data was examined in terms of the correlation between the reported GPA scores and a high correlation was found between the scores. Future studies can consider obtaining actual GPA scores through students' records from the school systems.

\section{Funding}

This research did not receive any specific grant from funding agencies in the public, commercial, or not-for-profit sectors.

\section{Conflicts of Interest}

I wish to confirm that there are no known conflicts of interest associated with this publication and there has been no significant financial support for this work that could have influenced its outcome.

\section{Author Bio}

Melih Dikmen graduated from Frrat University, Faculty of Education, Department of Computer Education and Instructional Technologies in 2011. Later, he received his master's degree from Yeditepe University Educational Sciences in 2015. Finally, he received his $\mathrm{PhD}$ in the field of Curriculum and Instruction at Firat University. 


\section{References}

Abdollahi, A., Abu Talib, M., Carlbring, P., Harvey, R., Yaacob, S. N., \& Ismail, Z. (2018). Problem-solving skills and perceived stress among undergraduate students: The moderating role of hardiness. Journal of Health Psychology, 23(10), 13211331. https://doi.org/10.1177/1359105316653265

Allen, T., Henderson, T., Mancini, V., \& French, K. (2017). Mindfulness and meditation practice as moderators of the relationship between age and subjective well-being among working adults. Mindfulness, 8, 1055-1063. https://doi.org/10.1007/s12671-017-0681-6

Arch, J. J., \& Craske, M. G. (2010). Laboratory stressors in clinically anxious and nonanxious individuals: The moderating role of mindfulness. Behaviour Research and Therapy, 48, 495-505. https://doi:10.1016/j.brat.2010.02.005

Arslan, I. (2018). The relationship between mindfulness, depression and perceived stress. Individual and Society Journal of Social Science, 8(2), 73-86.

Atanes, A. C., Andreoni, S., Hirayama, M. S., Montero-Marin, J., Barros, V. V., Ronzani, T. M., Kozasa, E. H., Soler, J., Cebolla, A., Garcia-Campayp, J., \& Demarzo, M. M. P. (2015). Mindfulness, perceived stress, and subjective wellbeing: a correlational study in primary care health professionals. BMC Complementary and Alternative Medicine, 15(1), 1-7. https://doi.org/10.1186/s12906-015-0823-0

Baer, R. A., Smith, G. T., Hopkins, J., Krietemeyer, J., \& Toney, L. (2006). Using selfreport assessment methods to explore facets of mindfulness. Assessment, 13, 27-45. https://doi.org/10.1177/1073191105283504

Bernal-Morales, B., RodríguezLanda, J. F., \& Pulido-Criollo, F. (2015). Impact of anxiety and depression symptoms on scholar performance in high school and university students, a fresh look at anxiety disorders. IntechOpen. https://doi.org/10.5772/60711

Biegel, G., \& Brown, K. (2010). Assessing the efficacy of an adapted in-class mindfulnessbased training program for school-age children: A pilot study. http:// www.mindfulschools.org

Bishop, S. R. (2002). What do we really know about mindfulness-based stress reduction?. Psychosomatic Medicine, 64(1), 71-83. https://doi.org/10.1097/00006842-200201000-00010

Braun-Lewensohn, O., Sagy, S., \& Al Said, H. (2014). Stress reactions and coping strategies among Bedouin Arab adolescents exposed to demolition of houses. Stress and Health: Journal of the International Society for the Investigation of Stress, 30(4), 333-342. https://doi.org/10.1002/smi.2519

Brooks, S. K., Webster, R. K., Smith, L. E., Woodland, L., Wessely, S., Greenberg, N., \& Rubin, G. J. (2020). The psychological impact of quarantine and how to reduce it: Rapid review of the evidence. The Lancet, 395(10227), 912-920. https://doi.org/10.1016/S0140-6736(20)30460-8

Brown, K. W., Kasser, T., Ryan, R. M., Linley, P. A., \& Orzech, K. (2009). When what one has is enough: Mindfulness, financial desire discrepancy, and subjective well- 
being. Journal of Research in Personality, 43(5), 727-736. https://doi.org/10.1016/j.jrp.2009.07.002

Brown, K. W., \& Ryan, R. M. (2003). The benefits of being present: Mindfulness and its role in psychological well-being. Journal of Personality and Social Psychology, 84(4), 822-848. https://doi:10.1037/0022-3514.84.4.822

Caballero, C., Scherer, E., West, M. R., Mrazek, M. D., Gabrieli, C. F., \& Gabrieli, J. D. (2019). Greater mindfulness is associated with better academic achievement in middle school. Mind, Brain, and Education, 13(3), 157-166. https://doi.org/10.1111/mbe.12200

Cabanilla-Pedro, L. A., Acob-Navales, M., \& Josue, F. T. (2004). Improving analyzing skills of primary students using a problem solving strategy. Journal of Science and Mathematics Education in S.E Asia, 27(1), 33-53.

Carmody, J., \& Baer, R. A. (2008). Relationships between mindfulness practice and levels of mindfulness, medical and psychological symptoms and well-being in a mindfulness-based stress reduction program. Journal of Behavioral Medicine, 31(1), 23-33. https://doi.org/10.1007/s10865-007-9130-7

Cash, M., \& Whittingham, K. (2010). What facets of mindfulness contribute to psychological well-being and depressive, anxious, and stress-related symptomatology? Mindfulness, 1(3), 177-182. https://doi.org/10.1007/s12671-0100023-4

Cenkseven-Önder, F., \& Utkan, Ç. (2018). The mediatory role of rumination and negative mood regulation in the relationship between mindfulness and perceived stress. Mersin University Journal of the Faculty of Education, 14(3), 1004-1019.

Chew-Graham, C. A., Rogers, A., \& Yassin, N. (2003). 'I wouldn't want it on my CV or their records': medical students' experiences of help-seeking for mental health problems. Medical Education, 37(10), 873-880. https://doi.org/10.1046/j.13652923.2003.01627.x

Choi, Y. B., Abbott, T. A., Arthur, M. A., \& Hill, D. (2007). Towards a future wireless classroom paradigm. International Journal of Innovation and Learning, 4(1), 1425.

Cohen, S., Kamarck, T., \& Mermelstein, R. (1983). A global measure of perceived stress. Journal of Health and Social Behavior, 24, 385-396. https://doi.org/10.2307/2136404

Curcio, G., Ferrara, M., \& De, G. L. (2006). Sleep loss, learning capacity and academic performance. Sleep Medicine Reviews, 105, 323-337. https://doi.org/10.1016/j.smrv.2005.11.001

De Lissnyder, E., Koster, E. H., Goubert, L., Onraedt, T., Vanderhasselt, M. A., \& De Raedt, R. (2012). Cognitive control moderates the association between stress and rumination. Journal of Behavior Therapy and Experimental Psychiatry, 43(1), 519525. https://doi.org/10.1016/j.jbtep.2011.07.004

Demir, M. (2019). Examining the relationship between problem solving, perceived stress and life satisfaction among college students [Unpublished master's thesis]. Istanbul Sabahattin Zaim University. 
Deniz, M. E., Erus, S. M., \& Büyükcebeci, A. (2017). Relationship between mindfulness and psychological well-being: The mediating role of emotional intelligence. Turkish Psychological Counseling and Guidance Journal, 7(47), 1731.

D'Zurilla, T. J., \& Nezu, A. M. (2001). Problem-solving therapies. In K. S. Dobson (Eds.), Handbook of cognitive-behavioral therapies (pp. 211-245). Guilford Press.

D'Zurilla, T. J., \& Nezu, A. M. (2007). Problem-solving therapy: A positive approach to clinical intervention (3rd ed). Springer Publishing Company.

Egan, H., \& Mantzios, M. (2018). A qualitative exploration of self-kindness and "treating oneself" in contexts of eating, weight regulation and other health behaviors: Implications for mindfulnessbased eating programs. Frontiers in Psychology, 9, 880. https://doi.org/10.3389/fpsyg.2018.00880

Elias, H., Ping, W. S., \& Abdullah, M. C. (2011). Stress and academic achievement among undergraduate students in Universiti Putra Malaysia. Procedia-Social and Behavioral Sciences, 29, 646-655. https://doi.org/10.1016/j.sbspro.2011.11.288

Elliot, A. J., Shell, M. M., Henry, K. B., \& Maier, M. A. (2005). Achievement goals, performance contingencies, and performance attainment: An experimental test. Journal of Educational Psychology, 97(4), 630-640. https://doi.org/10.1037/00220663.97.4.630

Eskin, M., Harlak, H., Demirkıran, F., \& Dereboy, Ç. (2013, October). The adaptation of the perceived stress scale into Turkish: A reliability and validity analysis. In New Symposium Journal, 51(3), 132-140.

Feizi, A., Aliyari, R., \& Roohafza, H. (2012). Association of perceived stress with stressful life events, lifestyle and socio-demographic factors: A large-scale community-based study using logistic quantile regression. Computational and Mathematical Methods in Medicine, 151865. https://doi.org/10.1155/2012/151865

Feldman, G., Greeson, J., \& Senville, J. (2010). Differential effects of mindful breathing, progressive muscle relaxation, and loving-kindness meditation on decentering and negative reactions to repetitive thoughts. Behaviour Research and Therapy, 48,1002-1011. https://doi:10.1016/j.brat.2010.06.006

Field, A. (2013). Discovering statistics using IBM SPSS statistics. Sage.

Flick, U. (2014). An introduction to qualitative research. Sage.

Florêncio, C. B. S., Ramos, M. F. H., \& Silva, S. S. D. C. (2017). Adolescent perceptions of stress and future expectations. Paidéia (Ribeirão Preto), 27(66), 6068. https://doi.org/10.1590/1982-43272766201708

Franco, C., Mañas, I., Cangas, A. J., \& Gallego, J. (2011). Exploring the effects of a mindfulness program for students of secondary school. International Journal of Knowledge Society Research, 2(1), 14-28. https://doi:10.4018/jksr.2011010102

Franco, C., Soriano, E. Y., \& Justo, E. (2010). Effect of a psychoeducational program in mindfulness on self-concept and academic performance of students American immigrants residing in Spain. Revista Iberoamericana de Educación, 53(6), 1-13.

Geiger, P. J., Boggero, I. A., Brake, C. A., Caldera, C. A., Combs, H. L., Peters, J. R., \& Baer, R. A. (2016). Mindfulness-based interventions for older adults: A review of 
the effects on physical and emotional well-being. Mindfulness, 7(2), 296-307. https://doi.org/10.1007/s12671-015-0444-1

Gilbert, P. (2005). Compassion: Conceptualizations, Research and use in psychotherapy. Brunner Routledge.

Glasow, P. A. (2005). Fundamentals of survey research methodology. https://www.mitre.org/sites/default/files/pdf/05_0638.pdf

Grossman, P., Niemann, L., Schmidt, S., \& Walach, H. (2004). Mindfulness-based stress reduction and health benefits: A meta-analysis. Journal of Psychosomatic Research, 57(1), 35-43. https://doi.org/10.1016/s0022-3999(03)00573-7

Gupta, M., Pasrija, P., \& Kavita. (2015). Effect of problem solving ability on academic achievement of high school students: A comparative study. Bhartiyam International Journal of Education \& Research, 4, 46-59.

Gürbüz, B. (2018). Universe and sample. https://acikders.ankara.edu.tr/pluginfile.php/105487/

Gürbüzer, M. (2016). Effects of stress on learning and student. http://www.konyayenigun.com/stresin-ogrenme-ve-ogrenci-uzerindeki-etkilerimakale,5301.html

Hair, J. F., Black, W. C., Babin, B. J., \& Anderson, R. E. (2010). Multivariate data analysis (7 ed.). Prentice-Hall, Inc.

Han, K. S. (2005). Self-efficacy, health promoting behaviors, and symptoms of stress among university students. Journal of Korean Academy of Nursing, 35(3), 585-592. https://doi.org/10.4040/jkan.2005.35.3.585

Hassan, N. M., \& Rahman, S. (2017). Problem solving skills, metacognitive awareness, and mathematics achievement: A mediation model. The New Educational Review, 49(3), 201-212. https://doi.org/10.15804/tner.2017.49.3.16

Hayes, A. F. (2013). Introduction to mediation, moderation, and conditional process analysis: A regression-based approach. The Guilford Press

Hayes, A. F. (2018). Introduction to mediation, moderation, and conditional process analysis: A regression-based approach (Second Edition). The Guilford Press.

Hede, A. J. (2017). Using mindfulness to reduce the health effects of community reaction to aircraft noise. Noise \& Health, 19(89), 165-173. https://doi.org/10.4103/nah.nah_106_16

Heppner, M. J., Lee, D., \& Paul Heppner, P. (2004). The role of problem-solving appraisal in the process and outcome of career counseling. Journal of Vocational Behavior 65(2), 217-238. https://doi.org/10.1016/s0001-8791(03)00100-3

Heppner, P. P., \& Petersen, C. H. (1982). The development and implications of a personal problem solving inventory. Journal of Counseling Psychology, 29, 66-75. https://doi.org/10.1037/0022-0167.29.1.66

Herath, H. M. W. (2019). Relationship between academic stress and academic achievements of the undergraduate students in Sri Lanka - A case study of undergraduates in Uva Wellassa University. https://socialscienceresearch.org/index.php/GJHSS/article/view/2884/2773 
Hittinger, S. M. (2018). The relationship between stress, social problem solving, and psychological distress in mothers of daughters with eating disorders [Doctoral dissertation]. Philadelphia College.

Hofer, M. (2007). Goal conflict and self-regulation: A new look at pupils' off-task behavior in the classroom. Educational Research Review, 2(1), 28-38. https://doi.org/10.1016/j.edurev.2007.02.002

Horan, K., \& Taylor, M. (2018). Mindfulness and self-compassion as tools in health behavior change: An evaluation of a workplace intervention pilot study. Journal of Contextual Behavioral Science, 8, 8-16. https://doi.org/10.1016/j.jcbs.2018.02.003

Infantolino, M. (2017). High school seniors' perceived stress of the college and career decision-making process [Master thesis]. State University of New York.

Janssen, M., Heerkens, Y., Kuijer, W., Van Der Heijden, B., \& Engels, J. (2018). Effects of Mindfulness-Based Stress Reduction on employees' mental health: A $\begin{array}{llll}\text { systematic } & \text { review. } & \text { PloS } & \text { one, 13(1), }\end{array}$ https://doi.org/10.1371/journal.pone.0191332

Kabat-Zinn, J. (1990). Full catastrophe living: Using the wisdom of your body and mind to face stress, pain, and illness. Random House, Inc.

Kabat-Zinn, J. (1994). Wherever you go, there you are: Mindfulness meditation in everyday life. NY: Hyperion.

Kaplan, H. I., \& Sadock, B. J. (2000). Learning theory: Synopsis of psychiatry: Behavioral sciences/clinical psychiatry. Lippincott Williams and Wilkins

Keng, S. L., Smoski, M. J., \& Robins, C. J. (2011). Effects of mindfulness on psychological health: A review of empirical studies. Clinical Psychology Review, 31(6), 1041-1056. https://doi.org/10.1016/j.cpr.2011.04.006

Kerlinger, F. N., \& Lee, H. B. (1999). Foundations of behavioral research. Harcourt College Publishers.

Kessler, R. C. (1997). The effects of stressful life events on depression. Annual Review of Psychology, 48(1), 191-214.

Khan, M. J., Altaf, S., \& Kausar, H. (2013). Effect of perceived academic stress on students' performance. FWU Journal of Social Sciences, 7(2), 146-151.

Klaassens, E. (1992). Strategies to enhance problem solving. Nurse Education, 17(3), 28-31. https://doi.org/10.1097/00006223-199205000-00014

Koole, S. L. (2009). The psychology of emotion regulation: An integrative review. Cognition \& Emotion, 23(1), 4-41. https://doi.org/10.1080/02699930802619031

Korkut, L. (2002). Problem solving skills of high school students. Hacettepe University Journal of Education Faculty 22, 177-184.

Kuncel, N. R., Credé, M., \& Thomas, L. L. (2005). The validity of self-reported grade point averages, class ranks, and test scores: A meta-analysis and review of the literature. Review of Educational Research, 75(1), 63-82. https://doi.org/10.3102/00346543075001063

Largo-Wight, E., Peterson, P. M., \& Chen, W. W. (2005). Perceived problem solving, stress, and health among college students. American Journal of Health Behavior, 29(4), 360-370. https://doi.org/10.5993/ajhb.29.4.8 
Lazarus, R. S., \& Folkman, S. (1984). Stress, appraisal, and coping. Springer Publishing Company.

Lee, J., Kim, E., \& Wachholtz, A. (2016). The effect of perceived stress on life satisfaction: The mediating effect of self-efficacy. Ch'ongsonyonhak Yongu, 23(10), 29.

Lee, J., Tran, T. T., \& Lee, K. P. (2007, July). Cultural difference and its effects on user research methodologies. In International Conference on Usability and Internationalization (pp. 122-129). Springer, Berlin, Heidelberg. https://doi.org/10.1007/978-3-540-73287-7_16

Leonard, N. R., Gwadz, M. V., Ritchie, A., Linick, J. L., Cleland, C. M., Elliott, L., \& Grethel, M. (2015). A multi-method exploratory study of stress, coping, and substance use among high school youth in private schools. Frontiers in Psychology, 6, 1028. https://doi.org/10.3389/fpsyg.2015.01028

Liu, Y. (2015). The longitudinal relationship between Chinese high school students' academic stress and academic motivation. Learning and Individual Differences, 38 , 123-126. https://doi.org/10.1016/j.lindif.2015.02.002

Lutz, A., Slagter, H. A., Dunne, J. D., \& Davidson, R. J. (2008). Attention regulation and monitoring in meditation. Trends in Cognitive Sciences, 12, 163-169. https://doi.org/10.1016/j.tics.2008.01.005

Marinoni, G., Van't Land, H., \& Jensen, T. (2020). The impact of Covid-19 on higher education around the world. IAU Global Survey Report.

Mehfooz, Q. U. A., \& Haider, I. S. (2017). Effect of stress on academic performance of undergraduate medical students. Journal of Community Med Health Education, 7(6), 566 .

Mertler, C. A. (2016). Introduction to educational research. Sage publications.

Miller, J. J., Fletcher, K., \& Kabat-Zinn, J. (1995). Three-year follow-up and clinical implications of a mindfulness meditation-based stress reduction intervention in the treatment of anxiety disorders. General Hospital Psychiatry, 17(3), 192-200. https://doi.org/10.1016/0163-8343(95)00025-m

Moattari, M., Abedi, H. A., Amini, A., \& Fathi, A. E. (2001). The effect of reflection on critical thinking skills of nursing students in Tabriz medical university. Iranian Journal of Medical Education, 1(4), 55-64.

Moore, K. A., \& Cooper, C. L. (1996). Stress in mental health professionals: A theoretical overview. International Journal of Social Psychiatry, 42(2), 82-89. https://doi.org/10.1177/002076409604200202

Moylan, S., Maes, M., Wray, N. R., \& Berk, M. (2013). The neuroprogressive nature of major depressive disorder: Pathways to disease evolution and resistance, and therapeutic implications. Molecular Psychiatry, 185, 595-606. https://doi.org/10.1038/mp.2012.33

Niemi, P. M., \& Vainiomäki, P. T. (1999). Medical students' academic distress, coping, and achievement strategies during the preclinical years. Teaching and Learning in Medicine, 11(3), 125-134. https://doi.org/10.1207/s15328015t1110302

Olendzki, N., Elkins, G. R., Slonena, E., Hung, J., \& Rhodes, J. R. (2020). Mindful hypnotherapy to reduce stress and increase mindfulness: A randomized controlled 
pilot study. International Journal of Clinical and Experimental Hypnosis, 68(2), 151-166. https://doi.org/10.1080/00207144.2020.1722028

Olgun, N., Öntürk, Z., Karabacak, Ü., Aslan, F., \& Serbest, Ş. (2010). Problem solving skills of the nursing students: Results of the 1-year observation problem solving skills of the students. Acıbadem University Journal of Health Sciences, 1(4),188194.

Osborne, J. W., \& Amy, O. (2004). The power of outliers (and why researchers should always check for them). Practical Assessment, Research \& Evaluation, 9(1), 6.

Özyazıcıŏlu, N., Aydınoğlu, N., \& Aytekin, G. (2009). The investigation of the problem solving and empathetic skills of the students in a school of health. Journal of Atatürk University School of Nursing. 12(3), 46-53.

Özyeşil, Z., Arslan, C., Kesici, Ş., \& Deniz, M. E. (2011). Adaptation of the Mindful Attention Awareness Scale into Turkish. Education and Science, 36(160), 224-235.

Park, H. J., Kim, M. Y., \& Jung, D. Y. (2008). The effect of stress, social support and self-efficacy on the mental health of female undergraduate students. Journal of Korean Academy of Fundamentals of Nursing, 15(4), 513-521.

Pascoe, M. C., Hetrick, S. E., \& Parker, A. G. (2020). The impact of stress on students in secondary school and higher education. International Journal of Adolescence and Youth, 25(1), 104-112. https://doi.org/10.1080/02673843.2019.1596823

Patel, C. (1989). Stress management. Vermilion Pres.

Perveen, K. (2010). Effect of the problem-solving approach on academic achievement of students in mathematics at the secondary level. Contemporary Issues in Education Research (CIER), 3(3), 9-14. https://doi.org/10.19030/cier.v3i3.181

Phillips, A. C. (2013). Perceived stress. In: Gellman M.D., Turner J.R. (Eds.) Encyclopedia of behavioral medicine. Springer. https://doi.org/10.1007/978-14419-1005-9_479

Rafidah, K., Azizah, A., Norzaidi, M. D., Chong, S. C., Salwani, M. I., \& Noraini, I. (2009). Stress and academic performance: Empirical evidence from university students. Academy of Educational Leadership Journal, 13(1), 37-51.

Ribeiro, I. J., Pereira, R., Freire, I. V., De Oliveira, B. G., Casotti, C. A., \& Boery, E. N. (2018). Stress and quality of life among university students: A systematic literature review. Health Professions Education, 4(2), 70-77. https://doi.org/10.1016/j.hpe.2017.03.002

Sagui-Henson, S. J., Levens, S. M., \& Blevins, C. L. (2018). Examining the psychological and emotional mechanisms of mindfulness that reduce stress to enhance healthy behaviours. Stress and Health, 34(3), 379-390. https://doi.org/10.1002/smi.2797

Schermelleh-Engel, K., Moosbrugger, H., \& Müller, H. (2003). Evaluating the fit of structural equation models: Test of significance and descriptive goodness-of-fit measures. Methods of Psychological Research Online, 8(2), 23-74.

Schiffrin, H. H., \& Nelson, S. K. (2010). Stressed and happy? Investigating the relationship between happiness and perceived stress. Journal of Happiness Studies, 11(1), 33-39. https://doi.org/10.1007/s10902-008-9104-7 
Shapiro, S. L., Astin, J. A., Bishop, S. R., \& Cordova, M. (2005). Mindfulness-based stress reduction for health care professionals: Results from a randomized trial. International Journal of Stress Management, 12(2), 164-176. https://doi.org/10.1037/1072-5245.12.2.164

Sharma, M., \& Rush, S. E. (2014). Mindfulness-based stress reduction as a stress management intervention for healthy individuals: A systematic review. Journal of Evidence-Based Complementary \& Alternative Medicine, 19(4), 271-286. https://doi.org/10.1177/2156587214543143

Sindhu, P. (2016). Impact of depression on academic achievement among engineering students. The International Journal of Indian Psychology 4, 49-50.

Sohail, N. (2013). Stress and academic performance among medical students. J Coll Physicians Surg Pak, 23(1), 67-71.

Tabachnick, B. G., \& Fidell, L. S. (2007). Experimental designs using ANOVA (p. 724). Belmont, CA: Thomson/Brooks/Cole.

Tan, C. S., Tan, S. A., Mohd Hashim, I. H., Lee, M. N., Ong, A. W. H., \& Yaacob, S. N. B. (2019). Problem-solving ability and stress mediate the relationship between creativity and happiness. Creativity Research Journal, 31(1), 15-25. https://doi.org/10.1080/10400419.2019.1568155

Taylan, S. (1990). Adaptation, reliability and validity study of Heppner's problem solving inventory [Unpublished master's thesis]. Ankara University.

Teodorczuk, K. (2013). Mindfulness and academic achievement in South African university students [Doctoral dissertation]. Johannesburg University.

Trautwein, U., Ludtke, O., March, H. W., Koller, O., \& Baumert, J. (2006). Tracking, grading, and student motivation: Using group composition and status to predict self-concept and interest in ninth-grade mathematics. Journal of Educational Psychology, 98(4), 788-806. https://doi.org/10.1037/0022-0663.98.4.788

Tuncer, M. (2017). A critical question: Can we trust smartphone survey data?. Journal of Education and Training Studies, 5(6), 33-43. https://doi.org/10.11114/jets.v5i6.2337

Vallejo, M. A., Vallejo-Slocker, L., Fernández-Abascal, E. G., \& Mañanes, G. (2018). Determining factors for stress perception assessed with the Perceived Stress Scale (PSS-4) in Spanish and other European samples. Frontiers in Psychology, 9, 37.

Veena, N., \& Shastri, S. (2016). Stress and academic performance. The International Journal of Indian Psychology, 3(4), 71-82.

Von der Heyde, E. M. (2017). The relationship between mindfulness and stress among college students [Doctoral dissertation]. Rowan University.

Walburg, V. (2014). Burnout among high school students: A literature review. Children and Youth Services Review, 28-33. https://doi.org/10.1016/j.childyouth.2014.03.020

Wallace, D. D., Boynton, M. H., \& Lytle, L. A. (2017). Multilevel analysis exploring the links between stress, depression, and sleep problems among two-year college students. Journal of American College Health, 653, 187-196. https://doi.org/10.1080/07448481.2016.1269111 
Wamsler, C. (2018). Mind the gap: The role of mindfulness in adapting to increasing risk and climate change. Sustainability Science, 13, 1121-1135. https://doi.org/10.1007/s11625-017-0524-3

Weinstein, N., Brown, K. W., \& Ryan, R. M. (2009). A multi-method examination of the effects of mindfulness on stress attribution, coping, and emotional well-being. Journal of Research in Personality, 43(3), 374-385. https://doi.org/10.1016/j.jrp.2008.12.008

Yu, M. O. (2018). The influence of nursing students' stress coping styles on problem solving ability. Journal of the Korea Academia-Industrial Cooperation Society, 19(3), 291-300. 